\title{
Studies on some fish parasites of public health importance in the southern area of Saudi Arabia
}

Estudos sobre alguns parasitas de peixes com importância para a saúde pública na região sul da Arábia Saudita Mokhtar Ibrahim Khalil ${ }^{1}$; Ismail Saad El-Shahawy ${ }^{1,2 *}$; Hussein Saad Abdelkader ${ }^{1}$

${ }^{1}$ Department of Applied Medical Sciences, Community College, Najran University, Najran, Saudi Arabia

${ }^{2}$ Department of Parasitology, Faculty of Veterinary Medicine, South Valley University, Egypt

Received March 12, 2014

Accepted May 27, 2014

\begin{abstract}
The present study was the first attempt to survey the diversity of fish zoonotic parasites in the southern region of Saudi Arabia, particularly the Najran area, from October 2012 to October 2013. Approximately 163 fish representing seven species (two of freshwater fish and five of marine fish) were examined for fish-borne trematode metacercariae using the compression technique, and for zoonotic nematode larvae. Adult flukes were obtained from cats experimentally infected with the metacercariae on day 25 post-infection The prevalence of each parasite species was recorded. The parasites found belonged to two taxa: Digenea (Heterophyes heterophyes and Haplorchis pumilio) in muscle tissue; and nematodes (larvae of Capillaria sp.) in the digestive tract. The morphological characteristics of the fish-borne trematode metacercariae and their experimentally obtained adults were described. This is the first report of these parasites in fish in Saudi Arabia. Moreover, Myripristis murdjan presented higher prevalence of Capillaria sp. infection (22.7\%), while Haplorchis pumilio was the dominant metacercarial species (7.9\%). Although the number of documented cases continues to increase, the overall risk of human infection is slight. The increasing exploitation of the marine environment by humans and the tendency to reduce cooking times when preparing seafood products both increase the chances of becoming infected with these parasites. Furthermore, our results indicate that certain fish production systems are at risk of presenting fish zoonotic parasites, and that control approaches will benefit from understanding these risk factors.
\end{abstract}

Keywords: Zoonotic parasites, fish, Najran, prevalence, Saudi Arabia.

\section{Resumo}

O presente estudo representa a primeira tentativa para investigar a diversidade dos parasitas zoonóticos em peixes na Região Sul da Arábia Saudita, em particular na área de Najran, de outubro de 2012 a outubro de 2013. Aproximadamente, 163 peixes representando sete espécies (duas de água doce e cinco marinhas) foram examinados para as metacercária, dos trematódeos de peixes, usando-se a técnica de compressão e para as larvas de nematoides. Os trematódeos adultos foram obtidos em gatos experimentalmente infectados com metacercárias no $25^{\circ}$ dia após a infecção. A prevalência de cada espécie parasita foi registrada. Os parasitas encontrados pertenciam a dois taxa: Digenea (Heterophyes heterophyes e Haplorchis pumilio) no tecido muscular; e nematoides (larvas de Capillaria sp.) no trato digestivo. As características morfológicas das metacercárias dos trematódeos de peixes e dos adultos experimentalmente obtidos são descritas. Esse é o primeiro relato desses parasitas em peixes da Arábia Saudita. Além desses, Myripristis murdjan apresentou alta prevalência de infecção por Capillaria sp. (22,7\%), enquanto Haplorchis pumilio foi a espécie de metacercárias dominante $(7,9 \%)$. Embora o número de casos documentados continue a aumentar, o risco global de infecção humana é pequeno. A exploração crescente do ambiente marinho pelos seres humanos e a tendência de reduçấo do processo de cozimento no preparo de alimentos oriundos do mar aumentam as chances de infecçấo por esses parasitas. Os resultados deste estudo também indicam que certos sistemas de produção de pescados estáo em risco de apresentar parasitas zoonóticos, e que o seu controle trará benefícios na compreensão destes fatores de risco.

Palavras-chave: Parasitas zoonóticos, peixes, Najran, prevalência, Arábia Saudita. 


\section{Introduction}

Food-borne parasitic infections have recently been identified as an important public health problem with considerable economic impact in terms of morbidity, loss of productivity and healthcare costs. Poor sanitation and traditional methods of food preparation have accelerated the spread of food-borne trematode infection (PHAN et al., 2010).

Fish are a good source of quality protein, but various diseases including parasitic infections pose a threat to fish cultivation, which is a valuable source of food and employment in developing countries (YOOYEN et al., 2006). In addition to the economic loss to farmers, many of the parasites, particularly trematodes, are also of zoonotic importance. Eating raw or improperly cooked or processed fish is the main source of these infections for humans, and this has been reported from various geographical regions (PARK et al., 2009). The World Health Organization (WHO) has estimated that the number of people currently infected with fish-borne trematodes exceeds 18 million, and many more are at risk (WHO, 1995).

Freshwater and brackish water fish play a major role as the source of human infections with food-borne trematodes, and these parasites are receiving increasing attention as information on their diversity and prevalence emerges in some Asian countries (WHO, 2004; CHAI et al., 2005; CHAI, 2007).

Although nematodes may be important pathogens of fish, of greater concern is usually their roles in transmitting parasites to humans, who become accidental hosts. Among the zoonotic nematode species that have been found, Capillaria philippinensis was first diagnosed in a Filipino patient who died of the infection some 40 years ago. Furthermore, zoonoses are today emerging over a wide geographical area extending from the Philippines, where infection occurs as small epidemics along rivers, to Egypt, where individual cases have been reported. Infection arises from fish that serve as intermediate hosts, thus resulting in chronic malabsorption syndrome, which has occasionally been reported to be fatal (CROSS et al., 1972).

In view of the importance of these parasites, the present study was therefore designed to study fish-borne parasitic zoonoses in the southern region of Saudi Arabia and to ascertain their infection status, taking in consideration their effect on fish health.

\section{Materials and Methods}

\section{Sample collection}

At weekly intervals over a one-year period, a total number of 163 different freshly captured freshwater fish [63 specimens of Oreochromis niloticus (L., 1758) and 20 of Mugil cephalus (L., 1758)] and marine fish [22 specimens of Myripristis murdjan (Murjan), 11 of Nemipterus nemurus (Handak), 16 of Mullus surmuletus (Sultan Ibrahim), 11 of Pomadasys multimaculatus (Naqror) and 20 of Carangoides hedlandensis (Byad)] were purchased at local fish markets in the Najran area, Saudi

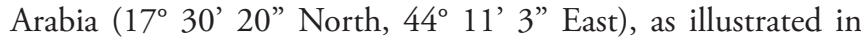
Figure 1. Their weights, standard lengths and total lengths were recorded. The fish were immediately subjected to parasitological examinations. Each sample was put into a clean plastic bag and was chilled to be sent to the laboratory of the Applied Science Department, Community College, Najran University, with a
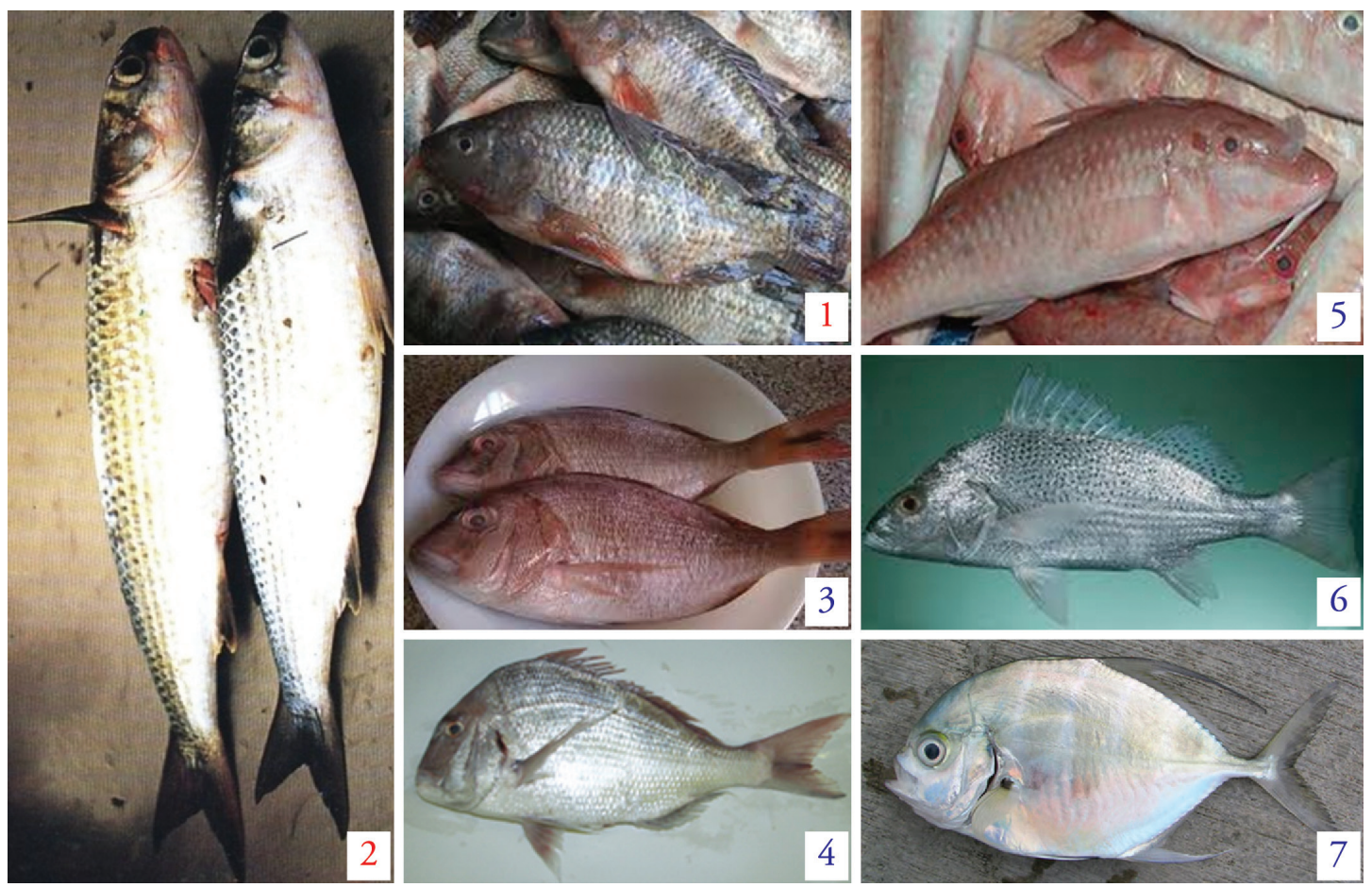

Figure 1. Fish species. 1- Oreochromis niloticus 2- Mugil cephalus 3- Myripristis murdjan (Murjan) 4- Nemipterus nemurus (Handak) 5- Mullus surmuletus (Sultan Ibrahim) 6- Pomadasys multimaculatus (Naqror) 7-Carangoides hedlandensis (Bayed). 
minimum of delay (SYME, 1966). In the laboratory, the fish specimens were pooled, sorted and identified to species level (SCHNEIDER, 1990).

\section{Parasitological examination}

Initially, each fish was screened for the presence of metacercariae by means of the compression method in which strips were taken from muscles in different regions of the body. Each specimen was compressed between two microscope glass slides and examined for the presence of metacercariae. The metacercariae were identified based on those preserved from fish tissues at the parasitology laboratory of the School of Veterinary Medicine, South Valley University. They were collected separately according to their general features and were tentatively identified to species level based on their morphological details and dimensions and whether they were found singly or in groups (ELSHEIKHA \& ELSHAZLY, 2008; SOHN et al., 2009).

The abdominal cavity of each fish was then cut open and the gastrointestinal tract was removed and cut into parts. This tract was separated from the other visceral organs and was placed in Petri dishes containing physiological saline. The intestines were further carefully slit open to aid the emergence of the parasitic helminths.

\section{Identification of metacercariae}

The metacercariae collected were measured under an optical microscope. Cats that were free from intestinal helminth infections according to fecal examination were orally fed with about 100 metacercariae and were sacrificed on day 25 post-infection (PI). The small intestine was resected, opened along the mesenteric border and washed several times with $0.85 \%$ saline. Adult flukes were recovered from the intestinal contents using Baermann's apparatus and were counted under a stereomicroscope. They were washed several times with saline, fixed in $10 \%$ neutral formalin, stained with acetocarmine, mounted in Canada Balsam and observed under an light microscope equipped with a micrometer scale. In the animal experiments, the guidelines for animal experiments specified by Najran University School of Medicine were followed (reference number: $\mathrm{Nu} 81 / 12$ ).

\section{Processing of recovered nematode larvae}

The nematode larvae recovered were fixed in 70\% alcohol and counted. They were then examined by means of light microscopy after clarified in lactophenol. Identification of the worms to species level was undertaken by using the available literature, based on their morphological features. Moreover, drawings were made using a camera lucida; all measurements were made in micrometers unless designated as millimeters.

\section{Histopathological study}

The gross lesions were recorded, and musculature specimens were collected and fixed in 10\% neutral buffered formalin solution. Paraffin sections of thickness five microns were prepared, stained with hematoxylin and eosin (H\&E) and examined under a microscope (BANCROFT \& STEVENS, 1996).

\section{Results}

\section{Survey analysis}

The present study was the first investigation of zoonotic parasites in commercially important fresh and marine water fish of the Najran region, Saudi Arabia.

Out of the 163 specimens studied, $17(10.4 \%)$ were found to be infected with zoonotic helminth parasites, of which $6(7.2 \%)$ were proved to be infected with encysted metacercariae, while 11 $(13.75 \%)$ were found to be positive for zoonotic nematode larvae.

Two species of trematode metacercariae (Heterophyes heterophyes and Haplorchis pumilio) were found in the fish from the Najran region. Heterophyes heterophyes metacercariae were detected in one fish species (Mugil cephalus), with a total infection rate of $5 \%$ and average number of metacercariae per infected fish of 1.3. On the other hand, metacercariae of Haplorchis pumilio were detected in Oreochromis niloticus, with overall prevalence of $7.9 \%$ and average number of metacercariae per infected fish of 3.4, as shown in Table 1 . No infection by metacercariae was recorded in the other marine water fish examined. Furthermore, metacercariae were found in the muscles of the caudal region of the fish examined.

In the present study, no relationship was observed between fish length and parasitism, given that the larger-sized fish were less affected by infection than the smaller-sized fishes. The highest numbers of fish infected by parasites were in the medium-sized class $(18.0-22.9 \mathrm{~cm})$.

Nematodes were only found as larval stages in the intestinal tract of the fish studied. Capillaria sp. larvae were found at an overall prevalence rate of $13.75 \%$, among which the rates were $15 \%$ in Bayed, 9.09\% in Handak, 22.7\% in Murjan, 6.25\% in Sultan Ibrahim and $9.09 \%$ in Naqror, as illustrated in Table 2.

The current study showed that Myripristis murdjan had the greatest diversity of Capillaria sp. larvae and that $H$. pumilio was the dominant metacercaria species. Furthermore, the present work provides the first record of the presence of these parasites in Saudi Arabia.

Table 1. Prevalence of zoonotic metacercariae among freshwater fish in Najran area, Saudi Arabia.

\begin{tabular}{lccc}
\multicolumn{1}{c}{ Freshwater fish species } & Number examined & Number positive & $\%$ \\
\hline Oreochromis niloticus & 63 & 5 & 7.9 \\
Mugil cephalus & 20 & 1 & 5 \\
Total & 83 & 6 & 7.2 \\
\hline
\end{tabular}




\section{Morphological results}

Morphology of the encysted metacercariae (based on five encysted metacercariae)

Heterophyes heterophyes metacercariae:

The metacercariae detected were yellowish brown in color and spherical, encircled by two thin layers; and measured 0.13-0.20 $\mathrm{mm}$ in diameter. The suckers were well developed and the ventral sucker was larger than the oral sucker. An elliptical genital sucker was observed, lying closely right laterally, posteriorly to the ventral sucker (Figure 2a).

\section{Metacercariae of Haplorchis pumilio:}

The cysts were elliptical, of major axis 150-180 (174) and minor axis 135-165 (150). They had 36-42 deer horn-like minute spines, arranged in 1-2 rows around the ventrogenital complex, and an O-shaped excretory bladder occupying a large portion of the posterior body, which appeared as a black excretory vesicle filled with the excretory granules at the caudal end (Figure $3 b$ ).

Morphology of adult flukes

Heterophyes heterophyes (Figures 2, b and c)

The body was small, pear shaped, flattened dorsoventrally, rounded at both extremities and $1.30-1.45 \mathrm{~mm}$ in length. The

Table 2. Prevalence of zoonotic Capillaria philippinensis larvae among marine fish in Najran area, Saudi Arabia.

\begin{tabular}{lccc}
\hline Marine fish species & Number examined & Number positive & \% \\
\hline Bayed & 20 & 3 & 15 \\
Handak & 11 & 1 & 9.09 \\
Murjan & 22 & 5 & 22.7 \\
Sultan Ibrahim & 16 & 1 & 6.25 \\
Naqror & 11 & 1 & 9.09 \\
Total & 80 & 11 & 13.75 \\
\hline
\end{tabular}

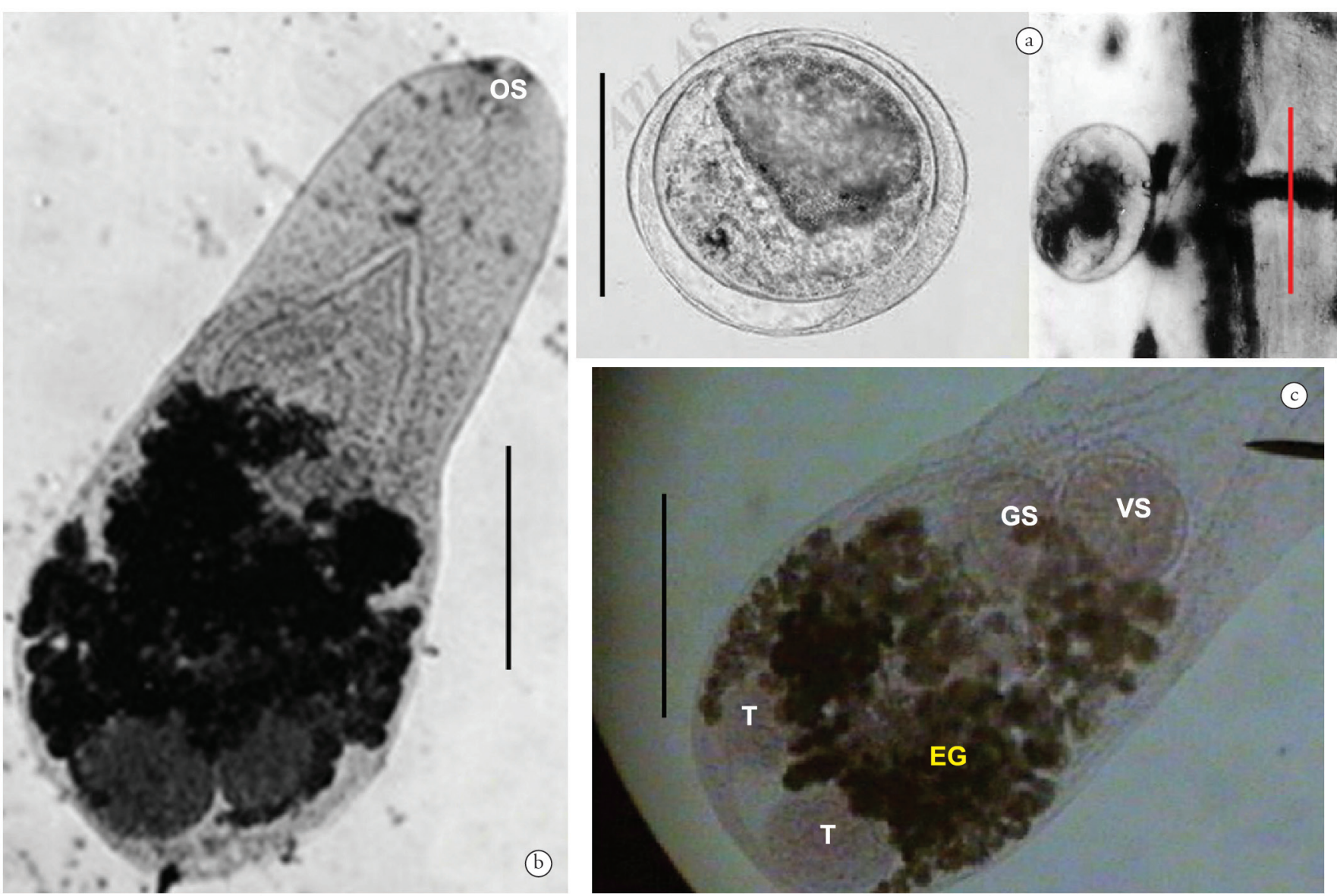

Figure 2. a- Heterophyes heterophyes metacercaria (unstained) (scale bar $=50 \mu \mathrm{m})$. b- Heterophyes heterophyes (acetocarmine stain) $(\mathrm{scale}$ bar $=100 \mu \mathrm{m})$, oral sucker (OS). c- Hind part of adult showing both ventral suckers (VS) and genital suckers (GS), testes (T) and eggs (EG) (scale bar = $100 \mu \mathrm{m})$. (acetocarmine stain). 

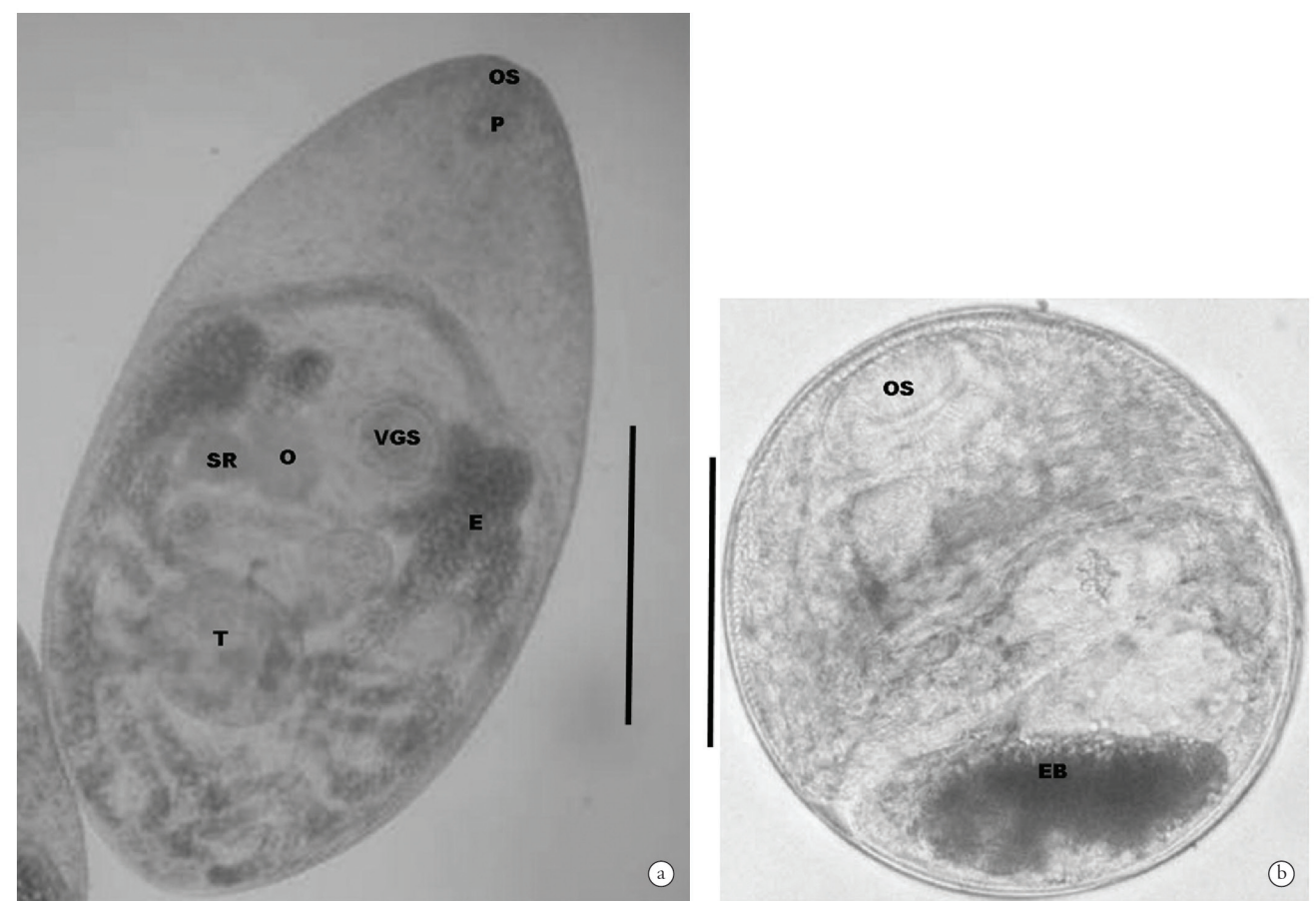

Figure 3. a- Haplorchis pumilio metacercaria with oral sucker (OS) and spherical excretory bladder (EB) $(\mathrm{scale}$ bar $=50 \mu \mathrm{m})$. b- Haplorchis pumilio adult with muscular oral sucker (OS), pharynx (P), ventrogenital sac (VGS) equipped with 36-42 deer horn-like minute spines, seminal receptacle $(\mathrm{SR})$, spherical ovary $(\mathrm{O})$ and single globular testis $(\mathrm{T})($ scale bar $=100 \mu \mathrm{m})$.

integument was furnished with spines from anteriorly to testes level. The oral sucker was subterminal. The pharynx was oval and 0.046-0.060 $\mathrm{mm}$ at its maximum diameter. The esophagus was slender and muscular, measuring $0.035-0.040 \mathrm{~mm}$ in length. The intestinal ceca reached the extremity of the body at posttesticular level. The ventral sucker was well developed, measuring $0.220-0.230 \mathrm{~mm}$ and lying in the middle of the body. The genital sucker was oval and disc-shaped, lying on the left side of the ventral sucker. The testes were oval in shape, lying in the hind part of the body side by side. The left testis was $0.132-0.137 \mathrm{~mm}$ in diameter and the right one was $0.116-0.11120 \mathrm{~mm}$. The ovary was round in shape, 0.73-0.99 $\mathrm{mm}$ in diameter, lying on the midline in front of the testes, with vitellaria lying between the levels of the ovary and testes with many spear-shaped follicles. The uterus filled the space between the ventral suckers and the testes.

\section{Haplorchis pumilio (Figure 3a)}

The body was small, pear-shaped, 415-550 (496) $\mu \mathrm{m}$ long and 195-245 (217) $\mu \mathrm{m}$ wide, with the greatest width at the middle, at the ovarian level. The oral sucker was subterminal: 43-50 (46) by 50-58 (54). The pharynx was elliptical: $25-33$ (29) by 20-30 (25). The esophagus was short: 40-83 (57) in length. The ventrogenital sac was small, with 36-42 deer horn-like minute spines. The ovary was spherical, 55-70 (62) by 30-68 (52), and slightly dextral to the midline. The testis was single, globular and 65-103 (82) by 75-105 (85), lying in the posterior quarter of the body. The uterus with eggs occupied an area from the anterior third to the posterior end (most of the hind body). The vitellaria was follicular, distributed in post-ovarian fields.

\section{Morphology of the larvae recovered (based on 20 larvae)}

\section{Capillaria spp.larvae}

The larvae were usually found embedded in the mucus coat of the intestinal tract of all the marine fish examined.

They were threadlike, with a body that was $0.55-0.70 \mathrm{~mm}$ long x 0.019-0.022 wide; narrow anteriorly and widening gradually posteriorly (Figure 4a). A spear was present; it was imperfectly sclerotized and its length was equal to about one third of the body width at the spear region (Figure $4 b$ ). The esophagus was 0.50-0.60 mm long, occupying nearly six-sevenths of the anterior portion of the body and lying to one side of the stichosome for a short distance anteriorly and then superficially to it (Figure 4a). The esophageal lumen was very narrow and indistinct anteriorly, widening gradually posteriorly and very distinct at its junction with the intestine. There were prominent cells with a conspicuous nucleus (probably coelomocytes) at the junction of the esophagus with the intestine (Figure 4c). The stichosome consisted of a single row of cells that was $0.46-0.55 \mathrm{~mm}$ in length (35 short stichocytes). The first cell was the longest and was slightly bilobate at its anterior extremity (Figure 4d). On the other hand, the cells in the anterior half varied in size and shape, and in the nature of the granules contained. The intestine was very short and only about one seventh of the body length; it consisted of large numbers of cells containing transparent globules and granules. The rectum was $0.034-0.050 \mathrm{~mm}$ in length, thin walled, narrow and tubular. The anus was terminal at the posterior end, and was round and bilobate (Figure 4c). It was not possible to distinguish the sexes at this developmental stage. 

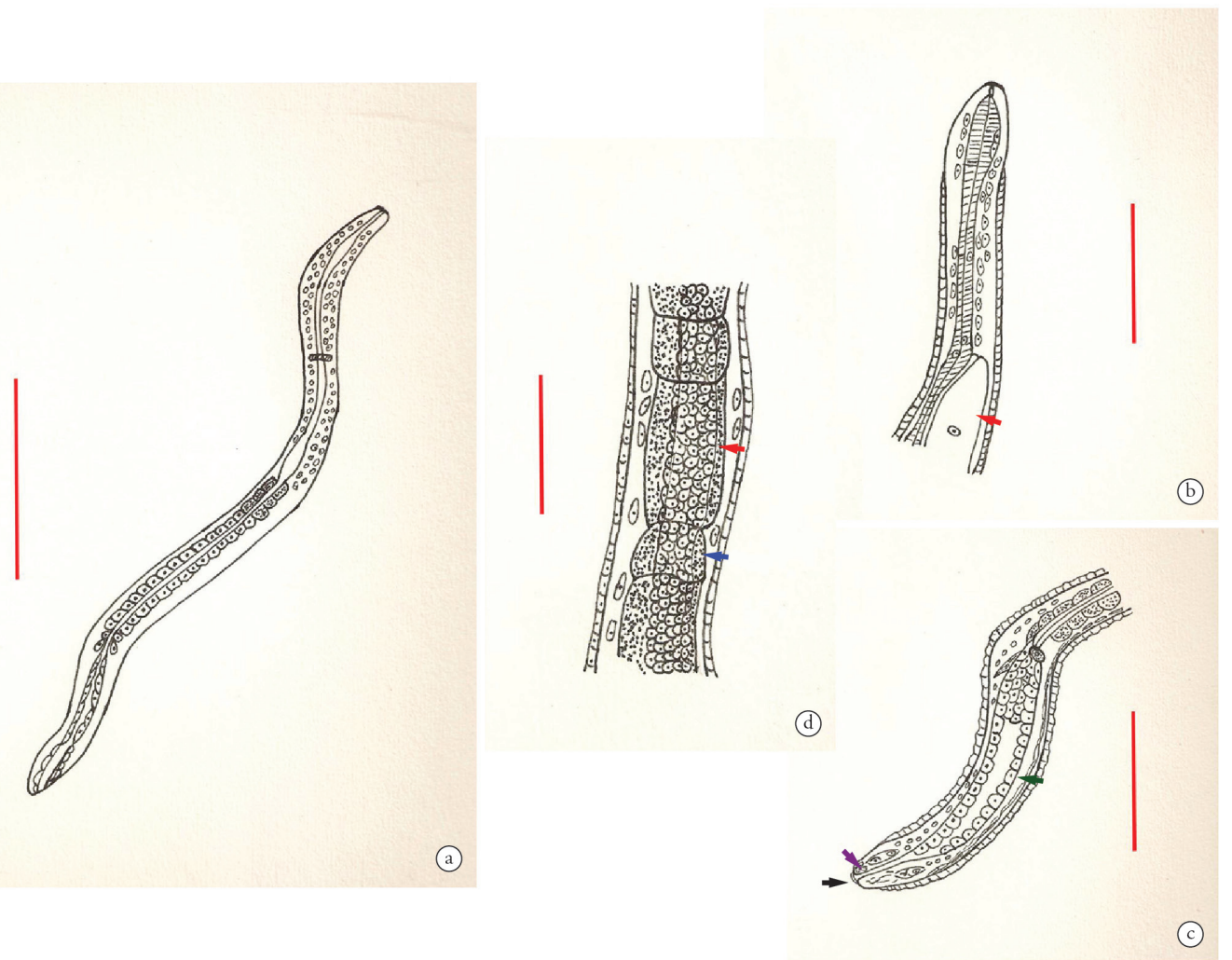

Figure 4. Line drawing of Capillaria sp. larva (scale bar $=0.05 \mathrm{~mm}$ ): a) whole larva (scale bar $=0.02 \mathrm{~mm}$ ); b) anterior end showing the esophagus, spears and long stichosome cells; c) posterior end showing the intestine and the intestinal cells (green arrow), rectum (red arrow) and anus (black arrow); d) lateral view showed the bacillary band, short stichosome cells (blue arrow) and long stichosome cells (red arrow).
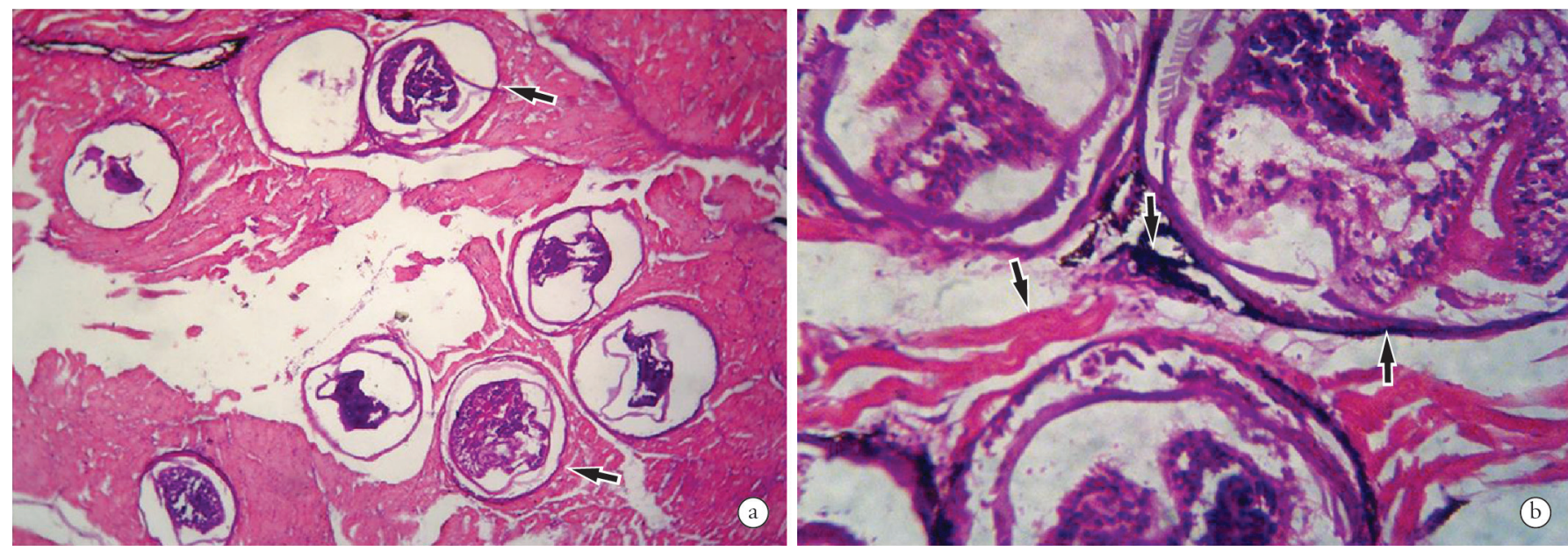

Figure 5. a- Muscle of fish infected with encysted metacercariae showing several cysts (H\&E; x200). b- Higher magnification of muscle infected with encysted metacercariae showing three cysts surrounded with dense fibrous tissue capsules (arrow) and melanomacrophages (arrow), along with hyalinization of muscle fibers (arrow) (H\&E; x400).

\section{Histopathological Findings}

Under the microscope, metacercariae were seen in almost all of the muscles of the caudal regions. Encysted metacercariae were seen inside round capsules and were surrounded by clear space. The fibrous capsule and surrounding muscle fibers showed mild hyaline degeneration and only a few inflammatory cell infiltrations (Figure 5, $a$ and $b$ ).

\section{Discussion}

There are relatively few studies on fish parasites in Arabian Gulf fish, especially with regard to the parasite-host relationship. Previous studies focused primarily on classifying the parasites of fish in the eastern Gulf (SAOUD, 1986, 1988; ELNAFFAR et al., 1992; AL-MATHAL, 2001; AL-ZUBAIDY \& MHAISEN, 2011). No data was available regarding zoonotic 
parasites in Saudi Arabia. Therefore, the present investigation was the first to consider them.

Through this study, the prevalence of heterophyid metacercariae was found to be $7.2 \%$. This finding was much lower than that reported among the Egyptian freshwater fish Oreochromis niloticus and Tilapia zillii in previous studies (ABDALLAH et al., 2009; IBRAHIM \& SOLIMAN, 2010).

More than 50 species of fish-borne intestinal flukes belonging to the Heterophyidae are widespread and emergent in Southeast Asia (DE et al., 2003), Thailand (WAIKAGUL \& RADOMYOS, 2005), Cambodia (STAUFFER et al., 2004), China (YU \& XU, 2005) and Korea (CHAI, 2005). With expanding freshwater and marine/brackish water fisheries in Asia, the economic impact on commercial aquaculture of fish-borne zoonotic trematode food quality and safety issues will become more burdensome (WHO, 2004; MURRELL \& CROMPTON, 2006; DUARTE et al., 2007). Variations in the percentage frequency of occurrence of encysted metacercariae (EMC) worldwide are expected and this may be attributed to various factors, including the locality from which the fish were caught; the degree of water pollution due to human, animal and bird excreta; and the feeding habits of the fish.

It is puzzling why zoonotic heterophyids have only recently been isolated from fish in Saudi Arabia. These parasites may have been recently introduced into this country and then became a zoonotic risk. Intensification of aquaculture, use of human and animal manure for pond fertilization, and increased consumption of fish because of increasing affluence among the population may be factors contributing towards infection. Use of manure and waste water in aquaculture is a well-recognized risk factor for trematode infections in fish (THU et al., 2007; HOP et al., 2007) and has been the focus of two hazard analyses in critical control point-based projects (CHAI et al., 2005).

The highest occurrence of heterophyid metacercariae was observed in the muscles of the caudal region of different fish species. Similarly, Haplorchis yokogawi metacercariae were found in the striated muscles of specimens of $O$. niloticus and T. zillii that were examined (IBRAHIM \& SOLIMAN, 2010). These findings reflect site preferences for each species, which in turn may be related to the difference in host species and location. It can be also concluded that the variation in the average number of encysted metacercariae in different species and in the body muscle region of these species may be attributed to different factors, namely, the type of encysted metacercariae and its preferred sites in fish. Most trematodes and their cercarial stages are highly specific in their selection of their definitive host and intermediate host and their tissue preferences. In addition, the physiological status of fish may play an important role in the degree of infection in different fish and organs (SHALABY et al., 1989).

With regard to fish length, the largest numbers of the fish infected by parasites belonged to the medium-sized class, i.e. 18.0-22.9 cm. Similarly, no correlation between fish length and infestation level have been reported in relation to plaice, Pleuronectes platessa (WICKINS \& MACFARLANE, 1973). On the other hand, there are studies in which it has been reported that parasitic infection increased with fish length, such as in herring, Clupea harengus (KHALIL, 1969); in English sole, Parophyrs velutus from the Oregon coast, USA (OLSON, 1978); and in hake, Merluccius gayi from Chile (CARVAJAL et al., 1979).

Although the morphological characteristics of fish-borne trematode metacercariae had previously been reported, we have redescribed some of their characteristic features to provide a useful aid for epidemiological studies in Asian countries. Among the fish-borne trematode metacercariae detected in our study, two species $(H$. heterophyes and $H$. pumilio) were morphologically identical with those from Egypt, China and Laos (RIM et al., 2008; SOHN et al., 2009). The experimentally obtained adults of the two species of fish-borne trematodes were morphologically compatible with those previously reported.

Larvae of the nematode species Capillaria sp. were observed parasitizing all examined marine water fish, with the highest peak among Myripristis murdjan (22.7\%). According to previous results, the larvae may be more dangerous than the adults, given that they can migrate through the fish to several target organs (DICK \& CHOUDHURY, 1995).

In conclusion, the present study has demonstrated that fish-borne zoonotic parasites occur in cultivated fish in Saudi Arabia and that this poses a potential risk to human health. At present, these parasites do not appear to represent a significant public health problem among the population in Najran city in particular, presumably because the local dietary habits do not favor consumption of raw fish. However, elsewhere in Saudi Arabia, there are many foreign Awsian people who have the habit of consuming improperly cooked fish. Therefore, these parasites may pose a greater threat to them, thus emphasizing the need to control these parasites in food for human use. Furthermore, the results from this study reported here strongly suggest that any efforts to control transmission will require control over infections in reservoir hosts and thorough control over snails in ponds. Further studies are needed in order to assess the epidemiological and biological status of fish zoonotic parasites in Saudi Arabia.

\section{Acknowledgements}

The authors are grateful to the Dean of scientific research at Najran University for supporting and funding this research. In addition, the authors extend their thanks to the reviewers for their time taken to carefully review our manuscript. We believe that their positive comments substantially improved this article.

\section{References}

Abdallah KF, Hamadto HH, El-Hayawan IA, Dawoud HA, Negm-Eldin M, Ahmed W-A. Metacercariae recovered from fresh-water fishes in the vicinity of Qualkyobia Governorate, Egypt. J Egypt Soc Parasitol 2009; 39(2): 467-477. PMid:19795754.

Al-Mathal EM. Six digenetic trematodes infecting the hamour fish (Epinephelus chlorostigma) in the Arabian Gulf, Saudi Arabia. J Egypt Soc Parasitol 2001; 31(3): 953-960, 1p. PMid:11775119.

Al-Zubaidy AB, Mhaisen FT. First record of Derogenes varicus and Dinurus scombri (Digenea: Hemiurata) from Red Sea fishes, Yemen. Mesopot J Mar Sci 2011; 26(2): 122-133. 
Bancroft JD, Stevens A. Theory and Practice of Histological Technique. 4th ed. New York: Churchill Livingston; 1996.

Carvajal J, Cattan PE, Castillo C, Schatte P. Larval anisakids and other helminths in the hake, Merluccius gayi (Guichenot) from Chile.J Fish Biol 1979; 15(6): 671-677. http://dx.doi.org/10.1111/j.1095-8649.1979. tb03676.x.

Chai JY. Intestinal trematode infections in Korea. In: Arizono N, Chai JY, Nawa Y, Takahashi Y, editors. Asian parasitology. Chiba: Federation of Asian Parasitologists; 2005. p. 79-102. vol. 1. Foodborne helminthiasis.

Chai JY, Murrell KD, Lymbery AJ. Fish-borne parasitic zoonosis: status and issues. Int J Parasitol 2005; 35(11-12): 1233-1254. http://dx.doi. org/ 10.1016/j.ijpara.2005.07.013.

Chai JY. Intestinal flukes. In: Murrell KD, Fried B. Food-Borne Parasitic Zoonoses: Fish and Plant-Borne Parasites. New York: Springer; 2007. p. 53-115. vol. 11. World Class Parasites.

Cross JH, Banzon T, Clarke MD, Basaca-Servilla V, Watten RH, Dizon JJ. Studies on the experimental transmission of Capillaria philippinensis in monkeys. Trans R Soc Trop Med Hyg 1972; 66(6): 819-827. http:// dx.doi.org/10.1016/0035-9203(72)90116-2. PMid:4631626

De NV, Murrell KD, Cong LD, Cam PD, Chau LV, Toan ND, et al. The food-borne trematode zoonosis of Vietnam. Southeast Asian J Trop Med Public Health 2003; 34(Suppl 1): 12-34. PMid:12971505.

DickTA, Choudhury A. Phylum nematoda. In: Woo, PTK. Fish diseases and Disorders. New York: CABE Publishing; 1995. p. 415-446. vol. 1. Protozoan and metazoan infections.

Duarte CM, Marbá N, Holmer M. Ecology. Rapid domestication of marine species. Science 2007; 316(5823): 382-383. http://dx.doi. org/10.1126/science.1138042. PMid: 17446380

El-Naffar MKI, Gobashy A, El-Etreby SG, Kardousha MM. General survey of helminth parasite genera of Arabian Gulf fishes (Coasts of United Arab Emirates). Arab GulfJ Sci Res 1992; 10(2): 99-110.

Elsheikha HM, Elshazly AM. Host-dependent variations in the seasonal prevalence and intensity of heterophyid encysted metacercariae (Digenea: Heterophyidea) in brackish water fish in Egypt. Vet Parasitol 2008; 153(1-2): 65-72. http://dx.doi.org/10.1016/j.vetpar.2008.01.026. PMID: 18339484

Ibrahim MM, Soliman MFM. Prevalence and site preferences of heterophyid metacercariae in Tilapia zilli from Ismalia fresh water canal, Egypt. Parasite 2010; 17(3): 233-239. http://dx.doi.org/10.1051/ parasite/2010173233. PMid:21073146

Hop NT, De NV, Murrell KD, Dalsgaard A. Occurrence and species distribution of fishbone zoonotic trematodes in wastewater-fed aquaculture in northern Vietnam. Trop Med Int Health 2007; 12(Suppl. 2): 66-72. http://dx.doi.org/10.1111/j.1365-3156.2007.01943.x. PMid:18005317

Khalil LF. Larval nematodes in the herring (Clupea harengus) frin British coastal waters and adjacent territories. JMar Biol Assoc UK 1969; 49(03): 641-659. http://dx.doi.org/10.1017/S002531540003719X.

Murrell KD, Crompton DWT. Foodborne trematodes and helminthes. In: Motarjemi Y, Adams M, editors Emerging foodborne pathogens. Cambridge: Woodhead Publishing in Food Science, Technology and Nutrition; 2006. p. 222-252.

Olson RE. Parasitology of English sole, Parophrys vetulus Girard in Oregon, USA. J Fish Biol 1978; 13(2): 237-248. http://dx.doi.org/ 10.1111/j.1095-8649. 1978. tb03431.x

Park CW, Kim JS, Joo HS, Kim J. A human case of Clinostomum complanatum infection in Korea. Korean J Parasitol 2009; 47(4): 401404. http://dx.doi.org/10.3347/kjp.2009.47.4.401. PMid:19967090
Phan VT, Ersbøll AK, Nguyen KV, Madsen H, Dalsgaard A. Farm-level risk factors for fish-borne zoonotic trematode infection in integrated small-scale fish farms in northern Vietnam. PLoS Negl Trop Dis 2010, 4(7): e742. PMid:20644617.

Rim HJ, Sohn WM, Yong TS, Eom KS, Chai JY, Min DY, et al. Fishborne trematode metacercariae detected in freshwater fish from Vientiane Municipality and Savannakhet Province, Lao PDR. Korean J Parasitol 2008; 46(4): 253-260. http://dx.doi.org/10.3347/kjp.2008.46.4.253. PMid:19127332

Saoud MFA. Helminth parasites of fishes from the Arabian gulf 1 . Preliminary general survey of fishes mainly from qatari waters. Qatar Univ Sci J 1986; 6: 199-229.

Saoud MFA. Helminth parasites of fishes from the Arabian Gulf: 4 On Allacanthochasmus lutjani n.sp. and Metadena leilae Nagaty, 1957 (Digenea: Cryptogonimidae). Qatar Univ Sci J 1988; 8: 161-172.

Shalaby SIA, Ibrahim M, Mahmoud NA. EL-Assely TM. Parasitological and pathological studies on encysted metacercariae in the musculature and different organs of Tilapia nilotica. Egypt J Comp Pathol Clin Pathol 1989; 2(1): 186-212.

Schneider W. FAO species identification sheets for fishery purposes. Field guide to the commercial marine resources of the Gulf of Guinea. Rome: FAO; 1990 .

Sohn WM, Na BK, Cho SH. Echinostoma hortense and heterophyid metacercariae encysted in yellowfin goby, Acanthogobius flavimanus, from Shinan-gun and Muan-gun (Jeollanam-do), Korea. Korean J Parasitol 2009; 47(3): 307-310. http://dx.doi.org/10.3347/kjp.2009.47.3.307. PMid:19724708

Stauffer WM, Sellman JS, Walker PF. Biliary liver flukes (Opisthorchiasis and Clonorchiasis) in immigrants in the United States: often subtle and diagnosed years after arrival. J Travel Med 2004; 11(3): 157-159. http:// dx.doi.org/10.2310/7060.2004.18100. PMid:15710057.

Syme JD. Fish and fish Inspection. 2nd ed. London: N K Lewis and co Ltd; 1966. p. 95-115.

Thu ND, Dalsgaard A, Loan LTH, Murrell KD. Survey for zoonotic liver and intestinal trematode metacercariae in cultured and wild fish in An Giang Province, Vietnam. Korean J Parasitol 2007; 45(1): 45-54. http://dx.doi.org/ 10.3347/kjp.2007.45.1.45

Waikagul J, Radomyos P. Intestinal trematode infections in Thailand. Asian Parasitology 2005; 1: 103-111.

Wickins JF, Macfarlane IS. Some differences in the parasitic fauna of three samples of plaice (Pleuronectes platessa L.) from the southern North sea. J Fish Biol 1973; 5(1): 9-19. http://dx.doi.org/10.1111/j.1095-8649.1973. tb04426.x.

World Health Organization - WHO. Control of Foodborne Trematode Infections. Geneva: WHO; 1995. 107 WHO Technical Report Series 849.

$<$ report $>$ World Health Organization - WHO. Joint WHO/FAO workshop on food-borne trematode infections in Asia. Hanoi, Vietnam: World Health Organization; Regional Office for the Western Pacific; 2004. 58 p. Report. $</$ report>

Yooyen T, Wongsawad C, Kumchoo K, Chaiyapo M. A new record of Clinostomum philippinensis (Valasquez, 1959) in Trichogaster microlepis (Gunther, 1861) from Bung Borapet, Nakhon Sawan, Thailand. Southeast Asian J Trop Med Public Health 2006; 37(Suppl 3): 99-103. PMid:17547061.

Yu SH, Xu LQ. Intestinal trematode infections in China. In: Arizono N, Chai JY, Nawa Y, Takahashi Y, editors. Asian parasitology. Chiba: Federation of Asian Parasitologists; 2005. p. 61-78. vol. 1. Foodborne helminthiasis. 